\title{
Project HOPE: American nurses in Brazil (1973)
}

\author{
Projeto HOPE: atuação de enfermeiras norte-americanas no Brasil (1973) \\ Proyecto HOPE: actuación de enfermeras norteamericanas en Brasil (1973)
}

\section{Laís de Miranda Crispim Costa',"I', Tânia Cristina Franco Santos', Luiz Otávio Ferreira"'I, Antônio José de Almeida Filho', Regina Maria dos Santos", Elaine Lázaro Alcántaralv}

\author{
' Universidade Federal do Rio de Janeiro, Nursing School Anna Nery. Rio de Janeiro, Brazil. \\ "Universidade Federal de Alagoas, Nursing \& Pharmacy School. Maceió, Alagoas, Brazil. \\ III Fundação Oswaldo Cruz, Oswaldo Cruz House, Research Department. Rio de Janeiro, Brazil. \\ IV Universidad Catolica Santo Toribio de Mogrovejo. Chiclayo, Peru.
}

How to cite this article:

Costa LMC, Santos TCF, Ferreira LO, Almeida Filho AJ, Santos RM, Lázaro Alcántara E. Project HOPE: American nurses in Brazil (1973). Rev Bras Enferm [Internet]. 2018;71(4):1956-62. DOI: http://dx.doi.org/10.1590/0034-7167-2017-0432

Submission: 06-18-2017 Approval: 08-31-2017

\section{ABSTRACT}

Objective: to describe the reality of nurses of Project HOPE and discuss the repercussion of their performance in relation to the reconfiguration of nursing in Alagoas State. Method: social-historical study, whose primary sources were documents filed in the Laboratory of Documentation and Research in History of Nursing, granted by this project; oral testimonies resulting from the transcription of interviews of US nurses and the VeNeta Masson's'logbook, coordinator nurse of the ship. The discussion of the data was based on Pierre Bourdieu's theory. The project was submitted to the Ethics Committee and approved by it. Results: The actions of the American nurses exposed the shortage of this type of professional in the area, as well as the precarious health conditions in the region. Conclusion: the symbolic capital of these nurses has contributed to the reconfiguration of the nursing field in Alagoas State.

Descriptors: Professional Autonomy; Female and Male Nurses; Nursing; History of Nursing; Nursing Care.

\section{RESUMO}

Objetivo: descrever as circusntâncias de atuação das enfermeiras do projeto HOPE e discutir as repercussões da atuação dessas enfermeiras em relação à reconfiguração da enfermagem alagoana. Método: estudo histórico-social, cujas fontes primárias foram documentos arquivados no Laboratório de Documentação e Pesquisa em História da Enfermagem, documentos cedidos pelo projeto HOPE, depoimentos orais resultantes da transcrição de entrevistas de enfermeiras norte-americanas e o diário de bordo da enfermeira VeNeta Masson, coordenadora de enfermagem do navio. A discussão dos dados teve como referencial a teoria de Pierre Bourdieu. O projeto foi submetido ao Comitê de Ética e foi aprovado. Resultados: as ações das enfermeiras norte-americanas expuseram a escassez desse tipo de profissional na área, bem como as precárias condições de saúde na região. Conclusão: o capital simbólico dessas enfermeiras contribuiu para a reconfiguração do campo da enfermagem em Alagoas.

Descritores: Autonomia Profissional; Enfermeiras e Enfermeiros; Enfermagem; História da Enfermagem; Cuidados de Enfermagem.

\section{RESUMEN}

Objetivo: describir las circunstancias de actuación de las enfermeras del proyecto HOPE y discutir las repercusiones de la actuación de esas enfermeras en relación a la reconfiguración de la enfermería del estado de Alagoas, Brasil. Método: el estudio histórico-social, cuyas fuentes primarias fueron documentos archivados en el Laboratorio de Documentación e Investigación en Historia de la Enfermería, documentos cedidos por el proyecto HOPE, testimonios orales resultantes de la transcripción de entrevistas de enfermeras norteamericanas y el diario de a bordo de la enfermera VeNeta Masson, coordinadora de enfermería del buque. La discusión de los datos tuvo como referencia la teoría de Pierre Bourdieu. El proyecto fue sometido al Comité de Ética y fue aprobado. Resultados: las acciones de las enfermeras norteamericanas expusieron la escasez de ese tipo de profesional en el área, así como las precarias condiciones de salud en la región. Conclusión: el capital simbólico de esas enfermeras contribuyó a la reconfiguración del campo de la enfermería en Alagoas.

Descriptores: Autonomía Profesional; Enfermeras y Enfermeros; Enfermería; Historia de la Enfermería; Cuidados de Enfermería. 


\section{INTRODUCTION}

The purpose of this study is to analyze the performance of American nurses of Project HOPE (Health Opportunity for People Everywhere) in the city of Maceió, in 1973. The arrival of the ship to the capital of the state of Alagoas was based on an agreement signed in 1972, between the government of the state, under Afranio Lages' term while governor, Project HOPE and the Federal University of Alagoas (Universidade Federal de Alagoas - UFAL). The training ship arrived at the port of Maceió City on February $15^{\text {th }}, 1973$ and had as one of its main purposes teaching technical procedures of the American medical science and professionals to properly care in special cases of health ${ }^{(1)}$.

Before the arrival of the ship, the society from Alagoas had only elementary nursing, represented by auxiliary and assistant nurses who worked in health servicies and performed a nursing subordinate to medical orders ${ }^{(1)}$. Until 1973, there were no undergraduate courses in nursing in Alagoas State and the few existing nurses worked in the Special Public Health Service Foundation (Fundação Serviço Especial de Saúde Pública) at the State Department of Health (Secretaria Estadural de Saúde) and the School of Nursing Assistants of Alagoas (Escola de Auxiliares de Enfermagem de Alagoas - EAEA), the only formal educational institution existing in the city, created in $1952^{(2-3)}$.

This is how the first undergraduate course in nursing in Alagoas State was created within UFAL, in the same year of the stay of the ship. It returned to Philadelphia, USA, in November 1973. It was not the purpose of Project HOPE to create a course in nursing, once it was already part of the policy by the Brazilian Ministry of Education and Culture (Ministério da Educação e Cultura do Brasil) to expand the number of schools in the country, specially in Federal Universities. Therefore, what happened was favorable, since the performance of American nurses provided a new vision of the potential of work of nurses and the great need for professionals of this level for Alagoas State.

\section{OBJECTIVE}

To describe the reality of nurses of Project HOPE and discuss the repercussion of their performance in relation to the reconfiguration of nursing in Alagoas State.

\section{METHOD}

\section{Ethical Aspects}

The ethical principles established under the Resolution 466, December $12^{\text {th }}, 2012$ by the Ministry of Health (Ministério da Saúde) were respected. The project was submitted to the Ethics Committee at Plataforma Brasil and approved with a Certificate of Presentation for Ethical Appreciation.

\section{Type of Study}

Historical-social research, which emphasizes the life of ordinary people and focuses on a more critical discussion from interpretative frames of reference ${ }^{(4)}$. We used in this study the theory of the social world by Pierre Bourdieu. The search for knowledge through historical research is as legitimate as in any other area of knowledge. The difference is the subject, the form of presentation of the data and the method ${ }^{(4)}$.

In this sense, the three steps of the historical method were followed, namely: data collection that has relation with the past; critical evaluation of these data; and presentation of the facts, interpretation of inferences and conclusions $s^{(5)}$. The social and temporal context was the municipality of Maceió, in 1973, during which time the HOPE ship was moored in the port of Jaraguá City, operating as a school Hospital.

\section{Methodological processes}

The primary sources were documents related to Project HOPE, filed in the Laboratory of Documentation and Research in History of Nursing (Laboratório de Documentação e Pesquisa em História da Enfermagem - LADOPHE) of the Federal University of Alagoas; documents provided by Project HOPE, such as: photographs, report of celebration for 50 years of the project and report of the stay of the ship in Maceió; oral testimonies resulting from the transcription of 2 interviews by US nurses belonging to the project; and Veneta Masson's journal, the coordinator nurse of the ship, published as a chapter in the book entitled "International Nursing"(6). This journal has testimonials from several US nurses involved in the project.

The inclusion criterion of the subjects was to belong to the nursing staff of the ship. Only one exclusion criterion was established, which was the impossibility for any reason to give an interview, e.g., health problems, impaired memory, etc. The secondary sources were composed by authors who addressed the History of Brazil, Alagoas State and Nursing, through which it was possible to correlate them with the primary sources and the theoretical reference chosen, to elucidate the proposed objectives. Regarding secondary sources, it should be emphasized that the search in national and international databases allowed us to find only three articles that deal with Project HOPE, expressing the need to publish about this theme that refers to the development of nursing in the world.

All documents were submitted to internal and external analysis. The internal checked the authenticity of the source and the external checked the content, to understand the meaning of its statement. In the data analysis, the historical context was correlated with the social structures existing in the field and with the symbolic universe of the statements, based on theoretical options, thematic choices and research hypotheses ${ }^{(7)}$. The discussion of the data was guided by the Social World Theory by the French sociologist Pierre Bourdieu, who recognizes that the actions of social groups can not be explained only as a combination of individual behaviors, but as a set of actions that incorporate cultural influences, traditions and objective structures within society. These influences are encompassed in his theory through the concepts of field, capital, and habitus, in order to ensure that the theory is fully representative of the social world"(8).

Bourdieu distinguishes four forms of capital: (1) economic capital, which can be immediately converted into cash; (2) cultural capital, which has greater relevance in his studies and refers to the intellectual qualification acquired through 
the family environment and educational processes; (3) social capital, which is the capital of social obligations and relations; and (4) symbolic capital, the status resulting from the possession of the capital forms mentioned above ${ }^{(9)}$.

Therefore, he considers that symbolic capital is the capital itself, be it of any kind: cultural, social, economic, political, sporting and artistic. The volume of efficient capital in a field determines which agent dominantly exercises the symbolic power over the dominated ${ }^{(10)}$.

\section{RESULTS}

The performance of the American nurses evidenced the shortage of this type of professional in Alagoas State, as well as the precarious health conditions of the region. It is possible to infer that the symbolic capital of these nurses contributed to the reconfiguration of the field of nursing in the location.

On February $15^{\text {th }}, 1973$, landed on Port of Jaraguá the training ship $\mathrm{HOPE}^{(2)}$. This ship was part of an international health care organization founded in $1958^{(11)}$, which was thought and encouraged by the then President of the United States, General Dwight Eisenhower, as well as by the Rockefeller Foundation, which had already funded other initiatives in Brazil, those related to the development of nursing personnel.

The ship, which formerly belonged to the US Navy, had to be refitted to become a school Hospital and to carry out its humanitarian aid trips to the less developed peoples, which lasted from 1960 to $1973^{(11)}$, according to Table 1:

Table 1 - Trips carried out with the ship of Project HOPE, Rio de Janeiro, Brazil, 2017

\begin{tabular}{ccc}
\hline Ordem & Country & Year \\
\hline $1^{\text {st }}$ & Indonesia & 1960 \\
$2^{\text {nd }}$ & Vietnam & 1961 \\
$3^{\text {rd }}$ & Peru & 1962 \\
$4^{\text {th }}$ & Ecuador & 1963 \\
$5^{\text {th }}$ & Guinea & 1964 \\
$6^{\text {th }}$ & Nicaragua & 1966 \\
$7^{\text {th }}$ & Colombia & 1967 \\
$8^{\text {th }}$ & Sri Lanka & 1968 \\
$9^{\text {th }}$ & Tunisia & 1969 \\
$10^{\text {th }}$ & West Indies & 1971 \\
$11^{\text {th }}$ & Brazil & 1972 \\
$12^{\text {th }}$ & Brazil & 1973 \\
\hline
\end{tabular}

The hospital ship HOPE left the Port of Baltimore, USA, in February 1973. According to the coordination of the project, the ship had a total of 206 people, including 60 nurses, 30 technicians, 6 doctors and 110 crew members, who, during the trip, took classes on Portuguese and Brazilian habits. In addition to the reffered above, other professionals of high qualification in their fields of activity in the health sector came from a special plane from Varig to the city of Recife, from where they were transported by bus to Maceió, the capital of the state of Alagoas ${ }^{(2)}$.
In this period Alagoas State did not have any undergraduate nursing course and the only existing formal institution was the $E A E A$, but its excessive rigor in the training process resulted in the slow expansion of auxiliary nursing professionals in the health services in the time and the nursing practice was implemented mainly by people without specific training, as in the case of nursing assistants ${ }^{(1)}$.

So, there was not any registered nurse in the hospitals, all sectors of the hospitals were managed by the nursing auxiliaries, because there was not even a technician and the care was performed by the attendants. Right, this was the reality. (American nurse 1)

This precarious health care accompanied the alarming indexes of social indicators, a fact that was obviously perceived by the members of the ship, according to the 50-year report of Project HOPE:

In some of the poorest regions of Brazil, children under five accounted for half of all deaths, and a shortage of medical personnel attempting to provide the necessary health care. Project HOPE addressed these great problems on its tenth and eleventh trips to Brazil. Project HOPE staff took care of every patient in their extreme needs. Inboard, they performed the first corneal transplant ever performed in the region. In addition to providing patient care, each case served as instruction, with Project HOPE personnel introducing their methods and technologies to their Brazilian counterparts. Project HOPE helped to create new care facilities, a post-graduate course in the medical-surgical area for the faculty of the federal university, and the first master's program in dentistry in Brazil(12).

In the case of nursing, due to the shortage of nurses, this interaction occurred with nursing assistants and attendants from various health services, with emphasis on Santa Casa de Misericórdia de Maceió, an institution where HOPE professionals also worked during the stay of the ship, because it was the place where the University Hospital operated under an agreement signed with the Medical Faculty of UFAL. Therefore, given that American nurses worked in several scenarios of care practice and with a counterpart system, one of them states:

But from the beginning, even from the time we were in the ship, when it came here we always worked, an American person with a Brazilian, we have never worked alone. (American nurse 1)

The operation of the nursing service at Santa Casa had specific characteristics, since the hospital had no nurses, just following what happened in virtually all the hospitals institutions of the state. Thus, the attendants, cupbearers, and servants, who performed the nursing care to internal patients were supervised by nuns. To alleviate this situation, UFAL hired a newly trained nurse in the city of Recife to work in partnership with the ship's nursing service throughout the period when it was moored in the port of Maceió ${ }^{(2)}$.

The hired nurse was Vera Lúcia Ferreira da Rocha, who went to work directly with the nursing coordinator of the project, 
Veneta Manson, materializing the counterpart system. Since it was not the purpose of the project to create a school to train nurses, the first steps taken by the ship's nursing team were the transfer of the UH to the university city, where there was already a building under construction for this purpose, as well as the training of nursing staff to work in the hospital after the change.

Our priority at that time was to set up the UH nursing service, it was one thing, the course started only a little later, in 1974. [...] So the first thing we did was to hire the nursing assistants to work at UH, we did all the interviews, practice classes and we selected the middle level staff. [...] We teached classes, classes and more classes, starting from absolutely basic, how to check the patient's temperature, how to check all the vital signs, bath in bed, we started everything, so when the hospital opened it was already with the team of nursing all formed by us. (American nurse 1)

Regarding the organization of the nursing of $U H$, the ship nursing coordinator's report proposed, at the time, eight objectives to be implemented to improve the quality of nursing care and to provide effective nursing care. This coordinator occupied the position of authorized spokesperson, because her speech concentrated the symbolic capital accumulated by the group (ship's nursing team) that gave her the mandate.

Objective number seven says that nursing, as an independent profession, must be recognized, respected and occupy a place of greater value within that hospital:

1. The University Hospital (UH) will have a nursing department with authority recognized by all intra and interdepartmental. 2 . The HU will have an orientation program organized for all nursing personnel adapted to the needs of the nursing team and the facilities available. 3 . The $\mathrm{HU}$ will have a nursing undergraduate school and will have completed the first class until the end of the agreement with Project HOPE. 4. The HU will have an ongoing in-service education program for all nursing staff addressing the needs of the various levels. 5. Nursing staff will be valued and will show interest in learning. 6 . The $\mathrm{HU}$ will have staff trained at the supervisory and head nurse levels to plan, implement and evaluate the educational program. 7. Nursing, as an independent profession, will be recognized, respected and trusted to a greater extent in the $\mathrm{UH}$ and in the community in general. 8. The HOPE nursing staff will be consulted and their talents used by UH colleagues and in the community ${ }^{(6)}$.

In this context, the medical category, which also acts directly in the care of the patients served by the project, could perceive this "new way of performing" nursing that was being introduced in the state.

The doctors here did not even know what nursing was, they understood nursing as simply being the nursing assistant, who used to say 'yes, sir, no sir', it's all ready. But, there was no one who could say 'Dr., but I think this is how it is supposed to be done.' (American nurse 1)

Of course we have many problems and a long way to go, but what is interesting is that we are able to offer a level of nursing care that has never existed in Maceió. It is not just the nursing level that is rising, but also the doctor's respect for the nursing staff. For example: when our head of pediatrics saw our first admission she found a sheet with accurate patient information and nursing notes on admission. She asked "Who filled in this sheet? This must be filled in by doctors." We showed her how we do this in nursing and how it can help the doctor to get the patient's history. She had no reaction! (American nurse 2)

The testimony reveals that a new way of performing nursing was being introduced in the field of health in Alagoas State, raising the level of the profession, specially capitalizing recognition by the medical category, which until then had dominated health care in the state:

Once more, one of the things Project HOPE has done, was to show what nursing is and how nursing and medicine can work together. [...] Doctors started working with American nurses and had a new perspective: what nursing means as a profession and how it could work in the professional motto. (American nurse 1)

Thus, autonomous nursing is apparent, leading to the deduction that the work of foreign nurses was essential to accelerate the process of creation of the first nursing undergraduate course in Alagoas State and the collaboration in its opening "was almost compulsory since doctors demonstrated in their actions the great need to have nurses in the state"(2).

Clearly, the need was immediately seen. Maceií City has no college, no higher-level nursing school, so the nurses are few here, and everyone has to come from abroad. We have to set up the nursing school. (American nurse 1)

The creation of new courses at UFAL is one of our concerns. However, we must remember that within the rationalization implemented in the country, such actions must be preceded by accurate feasibility studies, which will take into account several technical factors. [...] about the new courses suggested: Veterinary; Pharmacy; Nursing; Agronomy; and the most viable, now, is Nursing". (Official Letter $n^{\circ}$. 250/73-GR, of May 17, 1973, by the Dean of UFAL, Nabuco Lopes, to the Mayor of Maceió, José Figueiredo dos Santos)

Thereby, the Nursing Undergraduate course of UFAL was created. On July 19, 1973, the Dean at the time, Professor Nabuco Lopes, appointed a committee composed of two medical professors and a nurse hired by the University Hospital, the same who was the counterpart of nurse Veneta Mansson of Project HOPE, under Decree $N^{\circ}$. 259, to propose a curriculum for the course that was intended to be implemented at UFAL the following year.

The composition of the preliminary faculty of this course was extended beyond the graduation of the first class (June, 1977). It also counted on the performance of the nurses of Project HOPE, that even after the departure of the ship, was kept for another five years, carrying out an integrated program with the Government of Alagoas and UFAL ${ }^{(2)}$.

According to the project's nursing coordinator, she and seven other nurses remained in Maceió after the ship's departure to Philadelphia: 
We had to stay to help in the development of the new university hospital, located in the city's surroundings. Eight of us were nurses. (American nurse 3)

Two of the nurses who stayed in Alagoas, worked in public health care: Rosemary Zink, from Nevada, and Angela Lu Tena, from Peru. The other six were: Veneta Masson, from California, who worked in the education area; Dorothea Kipfer, from Switzerland, who worked in the UH operating room; Bárbara Allen, from Minessotta, who worked both in the Intensive Care Unit and in the Room of Recovery of the UH; Sheila Clarke, from Florida, who worked in pediatrics; Irene Bolton, from Nevada, who served in the Medical-Surgical Unit; and Ada Schoch, from California, who dealt with external patients ${ }^{(6)}$.

\section{DISCUSSION}

The theoretical framework chosen presupposes a theory of social structures, which aims to find logical or problematic plots that demonstrate the presence of an underlying social structure, in which social agents construct reality. Its method applies to the analysis of the production of ideas, the mechanisms of domination and the genesis of conducts ${ }^{(13)}$.

For Bourdieu, all real is relational, for in this conception the particular is not only part of the general, but there is a functional or dialectical interrelationship between the two. Based on this understanding, considering the work of the American nurses aboard the HOPE ship in Maceió, it could be said that this process has no meaning outside its relations with the whole ${ }^{(14)}$.

\section{The Brazilian Social and Political Situation and the Arrival of the Ship}

As far as the Brazilian political framework is concerned, this study is dated within the military dictatorship, which can be subdivided into four phases: 1) establishment of the dictatorialmilitary political regime (Castello Branco and Costa e Silva governments - March 1964 to December 1968); 2) consolidation of the regime (Medici government - 1969 to 1974); 3) transformation of the regime (Geisel government - 1974 to 1979); and 4) dissolution of the regime (Figueiredo government - 1979 to 1985$)^{(15)}$. Therefore, in the time context $(1973 / 1977)$ of the present study, we have two distinct governments, General Emílio Garrastazu Médici's and General Ernesto Geisel's.

The notion of authoritarianism is associated with these times. However, "there are even those who consider that, with the exception of the Medici period, post-1964 Brazil was more characterized by an authoritarian situation than by an authoritarian regime ${ }^{\prime \prime(16)}$. Certainly, the working class, the students and the peasants lost strength during this period, yet the left ideology remained predominant in universities, in some cultural circles and in trade unions, even with measures of repression against their leaders.

It was during the Medici period that the country experienced one of its darkest political moments ${ }^{(16)}$. The political repression was intensified, specially the persecution of the student movement. In Alagoas it was no different. During this period, the entire board of the Central Directory of Students (Diretório Central dos Estudantes - DCE) of the Federal University of
Alagoas was indicted and, with the arrest of the student leaders in 1973, the Dean of UFAL at the time, Professor General Nabuco Lopes, determines the shutdown of the headquarters of $D C E$, demonstrating the strong censorship of that moment ${ }^{(17)}$.

It is also under this government that we observe the period known as economic miracle, characterized by high growth rates of the Gross Domestic Product (GDP), accompanied by a decline in inflation and surpluses in the balance of payments. Although there is a range of studies about this phenomenon, there is no consensus among authors about the determinants of the referred "miracle"(18).

On the other hand, the process that supported the "economic model of the dictatorial cycle, had clearly defined objectives and causes, clearly identified subjects and beneficiaries, and a large contingent of sufficiently known affected people"(19). It was literally most of the Brazilian population because there was no concern with meeting the basic needs of citizens, but rather with building a strong military government.

In fact, the intensification of the Brazilian process of industrialization began in the 1950s, and during the period of the military dictatorship, the state induced a transition from tax incentives and investments in various economic sectors from the Southeast to the Northeast. Nevertheless, "due to its historical development, the state of Alagoas remains subject to the political control of the local rural oligarchies; and the action of the State to serve the interests of these still hegemonic oligarchies has been maintained"(20).

Following the unfolding of the national economy, the state of Alagoas was also benefited by the 'miracle', with the installation of some industries such as Mecânica Pesada Continental, Fives Lille-Cail and Salgema Indústrias Químicas S/A, making money flow into the Port of Jaraguá, which in 1974 was considered the second largest in the Northeast. However, this developmental outbreak was unable to absorb the entire reserve army of the state. "It was, unfortunately, the other face -the hidden faceof a savage and inhuman system, which privileges capital over labor" ${ }^{\prime \prime 17)}$. Given that, there is no way to deny the country's development at this stage and the capitalist expansion ${ }^{(21)}$. However, the greater part of Brazilian society did not take part in this process in a 'sustainable' and 'fair' way.

Thus, in the internacional context, Dr. Williams B. Walsh, a cardiologist in Washington, planned a health care program for the less developed peoples and was a leader of the ship's crew for 34 years, which is why he was honored by different awards ${ }^{(12)}$, including at UFAL, where received the title of professor "Honoris Causa". This award acclaimed Dr. Walsh, since such distinction constitutes an act of social magic capable of creating differences, recognizing competences, and instituting social distinctions. It is important to highlight that at the time, the USA was considered a booming superpower, evidenced by the record production of its industries, with an emphasis on arms development.

The ship, called the USS Consolation, with 15,000 tonnes "acts as a vehicle of the People to People Health Foundation, a privately funded project founded in 1958 by Dr. William Walsh of Washington. The Foundation is financed through voluntary contributions from industry and the American people". ${ }^{(22)}$

The table 1 draws attention to the fact that the only country visited twice by the ship was Brazil, and the first voyage occurred 
in 1972 to the city of Natal, capital of Rio Grande do Norte State. Probably because of the successful experience, there was an intercession by the Dean Nabuco Lopes, to articulate the displacement of the ship also to Alagoas State. This fact demonstrates the prospective vision of the Dean, who had, according to an article published on October $17^{\text {th }}, 1972$ in the main newspaper of the state -Gazeta de Alagoas- recently returned from the United States, established contact with the then governor of Alagoas, Afranio Lages, to deal with the arrival of the medical-hospital assistance mission as of February of the following year ${ }^{(2)}$.

\section{The stay of the ship in the city of Maceió and the symbolic} capital of the American nurses

With the arrival of the ship and the performance of all its staff in the provision of health and education services, Alagoas society begins to know a new way of performing nursing, based on the nightingaleano model in force in the United States in the 1970s. This is because, regarding nursing, the ship had only the nurses who had practiced the profession autonomously ${ }^{(1)}$.

Probably one of the determinants of this professional activity is the cultural capital inherited by the school and/or institution of origin of the foreign nurses. The inherited cultural capital, recognized as a seal, acts as a bridge to the insertion and occupation of social spaces, because the possession of certain social privileges is determined by properties that do not belong to the order of mere personal project, but which result from fairly objective distributive mechanisms, such as schooling, income and family tradition.

The sources consulted in this study emphasize Alagoas State as a very poor place, without health resources and with high infant mortality rate. Thus, Project HOPE, in addition to providing health care, used each case of patients as a way to teach their methods and technologies, through a counterpart system, where each American professional, from any area, worked with a Brazilian professional. "In applying Bourdieu's theory, the field should not be perceived as a single structure, but as a series of smaller social fields"(23).

Certainly, the professional capital of American nurses, possessing scientific knowledge and keeping the systematization of their work process, gained visibility in the society of Alagoas State, specially within the university, which only had two courses in the area of health: medicine and dentistry.

Therefore, regarding the astonishment of the chief doctor in the source who said that the medical record "must be completed by doctors", it can be inferred that nothing happened and the nurse performed the nursing record correctly; any order will only succeed if the person speaking has some authority to whom the call is intended. Therefore, "the magical effectiveness of these acts of institution is inseparable from the existence of an institution capable of defining the conditions (in terms of agent, place or moment, etc.) to be fulfilled so that the magic of words can operate" ${ }^{\prime \prime 24)}$.

It also appears that this context, in which American nurses developed autonomous nursing care, working as a member of the health team and not subordinated to the medical category prepared the scenario of symbolic struggles that would be waged during the implantation of the undergraduate course in nursing, which would be created at UFAL.
Moreover, several photographs analyzed in this study demonstrate the nurse as the protagonist of nursing care. In some cases, nurses are performing highly complex procedures; in others, physical examination and surrounded by doctors, and even teaching patients and their families about health education.

Finally, following the example of what happened at the creation of the School of Nursing of the National Department of Public Health (Departamento Nacional de Saúde Pública) in 1922, now known as the Anna Nery Nursing School, the American presence ends up imposing a legitimate worldview $^{(25)}$.

This happened because within this area, the training ship and the UH of UFAL, the dynamics of interaction between American and Brazilian nursing, whose agents (individuals or groups) had specific ways of thinking, of understanding the world and acting; that is, they had a habitus. The mentioned area maintained dialectical relation (of mutual influence) with the values or forms of cultural and social capital of its occupants.

Consequently, the influence of American nursing was also remarkable in the first years of operation of the newly created course in Alagoas, but this is a different story.

\section{Study limitations}

We have as study limitations the perception of the authors, who write from a social place and a point of view crossed by individualities. Thus, producing a historical study considers multiple influences, related to a certain community (the univeristy, as in the present case), which is updated by its own time.

Contributions to the nursing, health or public policy sectors As social relevance, the objective is to contribute to record and spread the History of Brazilian Nursing, specially the insertion of modern nursing in Alagoas State, Brazil, with emphasis on the meeting between American and Brazilian nursing. Therefore, teaching and sharing important aspects of history provides, among other contributions, the development of a lasting commitment to the profession.

\section{CONCLUSION}

This paper deals with questions about the reconfiguration of nursing in Alagoas, based on the work of a group of American nurses linked to Project HOPE.

Written and oral documents made it possible to say that foreign nurses who had cultural, personal and nursing traits different from those found in Brazil, especially in Maceió City, Alagoas, were able to cope with changes in their practice, with an emphasis on the autonomy of the practice of nursing care. Also, we could see recognition of nursing as an important and essential profession for the success of health care, in the systematization of care, in the organization of the nursing service of the University Hospital and in the recruitment, training and teaching nursing auxiliaries in the locality.

Finally, the anchorage of the ship in Alagoas provided sharing nursing knowledge, in which the symbolic capital of American nurses reconfigured the nursing field in Alagoas. Moreover, it compulsorily contributed to the process of creation of the first undergraduate course in nursing in the state, the Federal University of Alagoas. 


\section{REFERENCES}

1. Costa LMC, Santos RM, Santos TCF, Trezza MCSF, Leite JL. Project HOPE contribution to the setting up of the professional identity of the first nurses from Alagoas, 1973-1977. Rev Bras Enferm[Internet]. 2014[cited 2017 Jun 19];67(4):535-42. Available from: http://www.scielo.br/pdf/reben/v67n4/0034-7167-reben-67-04-0535.pdf

2. Santos RM, Lira YCMS, Nascimento RF. O navio HOPE: um novo encontro entre a enfermagem brasileira e a norte-americana. Maceió: Edufal; 2009.

3. Silva NAR, Santos RMS, Macedo AC, Costa LMC, Santos JFE. The struggle for civil organization of nursing of the Alagoas: the creation of Brazilian Association of Nursing-AL (1962-1965). Hist Enferm Rev Eletr[Internet]. 2015[cited 2017 Jun 19];6(1):21-36. Available from: http://here.abennacional.org.br/here/2_AO_05015_MM.pdf

4. Fealy GM. Historical Research. In: Watson R, McKenna H, Cowman S, Keady J, (Eds.). Nursing Research: designs and methods. New York: Churchill Livingstone Elsevier; 2008. p. 45-54.

5. Padilha MICS, Borenstein MS. The methodology of historic research in the nursing. Texto Contexto Enferm[Internet]. 2005[cited 2017 Jun 18];14(4):575-84. Available from: http://www.scielo.br/pdf/tce/v14n4/a15v14n4.pdf

6. Masson V. Internacional Nursing. New York: Springer Publishing Compan; 1981.

7. Cardoso CF, Vainfas R. Domínios da História: ensaios de teoria e metodologia. Rio de Janeiro: Campus; 1997.

8. Rhynas SJ. Bourdieu's theory of practice and its potential in nursing research. J Adv Nurs[Internet]. 2005[cited 2017 Jun 18];(50)2:179_ 86. Available from: https://www.ncbi.nlm.nih.gov/pubmed/15788082

9. Sieger M, Fritz E, Them C. In discourse: Bourdieu's theory of practice and habitus in the context of a communication-oriented nursing interaction model. J Adv Nurs[Internet]. 2012[cited 2017 Jun 18];(68)2:480-9. Available from: https://onlinelibrary.wiley. com/doi/abs/10.1111/j.1365-2648.2011.05783.x

10. Bourdieu P. A economia das trocas simbólicas. São Paulo: Perspectiva; 1999.

11. Thiry-Cherques HR. Pierre Bourdieu: the theory in practice. Rev Adm Pública[Internet] 2006[cited 2017 Jun 16];40(1):27-55. Available from: http://www.scielo.br/pdf/rap/v40n1/v40n1a03.pdf

12. Bourdieu P. O poder simbólico. 15th ed. Rio de Janeiro: Bertrand Brasil; 2011.

13. Codato AN. Uma história política da transição brasileira: da ditadura militar à democracia. Rev Soc Pol[Internet] 2005 [cited 2017 Jun 16];25:83-106. Available from: http://www.scielo.br/pdf/rsocp/n25/31113.pdf

14. Fausto B. História do Brasil.13th ed. São Paulo: Edusp; 2010.

15. Queiroz A. Episódios da História de Alagoas. 2a ed. Maceió: Edições Catavento; 1999.

16. Veloso FA, Villela A, Giambiag F. Determinantes do "milagre" econômico brasileiro (1968-19732): uma análise empírica. Rev Bras Econ[Internet]. 2008[cited 2017 Jun 16];62(2):221-46. Available from: http://www.scielo.br/pdf/rbe/v62n2/06.pdf

17. Netto JP. Pequena história da ditadura brasileira, 1964-1985. São Paulo: Cortez; 2014.

18. Lira S. Alagoas 2000-2013. São Paulo: Editora Fundação Perseu Abramo; 2014.

19. Napolitano M. 1964: História do Regime Militar Brasileiro. 1th ed. São Paulo: Contexto; 2014.

20. Rominski SD, Yakubu J, Oteng RA, Peterson M, Tagoe N, Bell SA. The role of short-term volunteers in a global health capacity building effort: the Project HOPE-GEMC experience. Int J Emerg Med[Internet] 2015[cited 2017 Jun 15];23(8):1-5. Available from: https://www.ncbi.nlm.nih.gov/pmc/articles/PMC4508279/pdf/12245_2015_Article_71.pdf

21. Fifty years of Project HOPE. Virginia: International Headquarters_Project HOPE; 2007.

22. Shepherd RW. The SS HOPE in Peru. Canad Med Ass J[Internet] 1963[cited 2017 Jun 15];15:1201-4. Available from: https://www. ncbi.nlm.nih.gov/pmc/articles/PMC1921395/pdf/canmedaj01000-0028.pdf

23. Petit-dit-Dariel O, Wharrad H, Windle R. Using Bourdieu's theory of practice to understand ICT use amongst nurse educators. Nurse Educ Today [Internet]. 2014[cited 2017 Jun 15];34(11):1368-74. Available from: https://linkinghub.elsevier.com/retrieve/ pii/S0260-6917(14)00046-X

24. Bourdieu P. A economia das trocas linguísticas: o que falar quer dizer. 2th ed. São Paulo: EDUSP; 1998.

25. Santos TCF, Lopes GT, Porto F, Fonte AS. Opposition to the american leadership by brazilian nurses(1934-1938). Rev Latino-Am Enfermagem[Internet]. 2008[cited 2017 Jun 19];16(1):130-5. Available from: http://www.scielo.br/pdf/rlae/v16n1/19.pdf 